\title{
GROUNDS FOR THE MODIFICATION OF ALIMONY AWARDS
}

\author{
Eugene Desvernine*
}

A fertile field of litigation in the realm of domestic relations arises in connection with the modification of divorce decrees relating to alimony. The frequency with which divorced parties seek judicial amendment of the orders awarding alimony indicates the social significance of the matter and warrants an investigation of the bases upon which the courts operate in determining such controversies. ${ }^{1}$ With this objective in view a study has been made of all the cases involving modification of alimony decrees which reached the appellate courts during the period comprehended between the years 1926 to 1938 inclusive. ${ }^{2}$ Proper treatment of all the issues which arise in such cases would necessitate an inquiry into a diversity of legal problems, such as the existence and extent of the judicial power of revision, which lie beyond the scope of this paper. ${ }^{3}$ Attention, therefore, will be focused exclusively on the substantive considerations which determine whether or not a given award will be changed as revealed by the cases examined.

At the outset much confusion will be avoided by an exposition of the distinction between the modification of a decree awarding alimony by an appellate court to which the case has been brought on appeal from the decision in the original divorce court,

* A.B., Duke University, 1937; third year student at Duke Univesity School of Law. Member of the editorial board of the Duke Bar Association Journal.

${ }^{1}{ }^{4} 2$ cases involving revision of alimony orders are cited by the Third Decennial Digest, I916-1926; for the following decade the Fourth Decennial cites 253 such cases. In view of the fact that these citations represent mainly appellate decisions, the number appears to be substantial.

${ }^{2}$ The cases cited by the Fourth Decennial Digest, $1926-1936$, and the yearly Digests for 1936, 1937, and r938 have been analyzed. Although the selection of this period has been in a large measure arbitrary, due regard was had for the importance of contemporary decisions in a field where the law is undergoing rapid evolution.

${ }^{3}$ Perhaps the most consequential of these problems relates to the power to modify or cancel past-due installments of alimony. The majority of states deny the power as to such installments, but a minority permit modification. See 2 Schouler, Marriage, Divorce, Separation, and Domestic Relations (6th ed. I921) $\$ \times 830$; cf. Jacobs, The Enforcement of Foreign Decrees for Alimony, infra. p. 261, notes 70, $7 x$.

Much litigation has arisen as to the extent of the court's power to modify decrees entered by consent. Where the court has approved an agrecment between the partics relating to alimony, this is generally regarded as a contract which cannot be modified except by the parties themselves. 17 AM. Jur. (1938) \$649. Contra: Low v. Low, 79 Colo. 408, 246 Pac. 266 (1926); Herrick v. Herrick, 319 Ill. 146, 149 N. E. 820 (1926). However, the decree may be altered to the extent that it is not dependent on the partics' agreement. 17 ANr. JUR. 5649 . As to what constitutes a reservation of a power to modify a decree based on agreement, compare Crawford v. Crawford, I29 Misc. 683, 221 N. Y. Supp. 55 I (1927), and Folz v. Folz, 42 Ohio App. 135, r8x N. E. 658. On the power to modify decrees based on agreements, sec (1933) 19 VA. L. Rev. 513; (1937) 22 WAsh. UNIv. L. Q. 263, 392; (1938) 26 CAL. L. Rev. 491, 707. 
and modification of a decree upon independent petition by one of the parties. Aside from procedural differences, the distinction is important in that the rules which determine a court's disposition of a case in each situation are widely dissimilar. In the former the court is concerned with the propriety of the lower court's decision on the facts and evidence introduced before it, whereas in the latter the decision of the original divorce tribunal is not open to attack and the court is exclusively concerned with the situation of the parties as it exists at the time of the petition. There is no time limitation operating against a party who seeks revision of an alimony decree by the second method, and no restriction on the number of times a petition may be brought. Courts are wary of attempts by parties to a divorce proceeding to appeal from the part of the decree with which they are dissatisfied without complying with the statutes and rules governing appeals, and will not entertain a petition unless properly supported by a showing of the required conditions. ${ }^{4}$

The rule which permits a change in the terms of the alimony decree to conform to new circumstances is derived from the ecclesiastical courts, which restricted it to cases of limited divorce. ${ }^{5}$ Where an absolute divorce has been granted it is generally held in this country that the power to alter a decree after it has been made does not exist in the absence of the reservation of such power in the decree itself, or of statutory authority. ${ }^{6}$ Such statutes may be found in the majority of the American jurisdictions, ${ }^{7}$ and the matter is usually left within the discretion of the court to make such revision "as circumstances may require,"8 "as may be proper,"9 "as the case may require," 10 etc. Unless extraordinary circumstances justify such a course, the modification will not be made by the court on its own motion, but will be considered only upon application by one of the parties. ${ }^{11}$ Courts make the granting of relief dependent upon the showing of "changed circumstances,"12 "changed conditions,"13 "a change in the situation of the parties,"14 or a showing that the original decree is "no longer fair and just."15 Therefore, a petition which fails to allege that the conditions upon which the relief is predicated did not exist at the time of the rendition of the final divorce decree is fatally defective. ${ }^{16}$ Occasionally, however, it is

\footnotetext{
"Glad v. Glad, 5I S. D. 574, 215 N. W. 93 (I937).

'See Alexander v. Alexander, I3 App. D. C. 334 (1898).

${ }^{\circ}$ Schourer, op. cit. supra note $3, \S 1828$. Statutes granting the courts power to modify alimony decrees are held not to apply where no alimony has been granted in the original decree. Id. $\$ 1807$. A decree awarding alimony in gross may not be modified after full performance. Id. $\$ 1830$.

${ }^{7}$ For a compilation of the statutory authority on this subject, see 2 VERNIER, AMrRrcan FamLY LAws (1932) \$ro6, Table LIV and r938 Supplement. ${ }^{8}$ N. J. Rev. STAT. (I937) \$2:50-37.

${ }^{0}$ Mo. Rev. Star. (I929) \$\$1355, I361.

${ }^{11}$ In MicPartland v. McPartland, I46 Misc. 672, 26I N. Y. Supp. 844 (I933), where the husband was imprisoned for contempt for failure to pay alimony, the court modified the order on its own motion to exempt him from making the payments during his imprisonment. Likewise, in Andrews v. Andrews, 144 Orc. 200, 24 P. (2d) 332 (1933), the court reduced the alimony when it found the husband had become a paralytic cripple, upon citation for contempt for failure to make the payments.

${ }^{12}$ Smith v. Smith, 334 Ill. 370, I66 N. E. 85 (1929).

${ }^{13}$ Badger v. Badger, 69 Utah 293, 254 Pac. 784 (1927).

${ }^{2}$ Holida v. Holida, 183 Minn. 618,237 N. W. 2 (I93I).

${ }^{25}$ Low v. Low, 79 Colo. 408, 246 Pac. 266 (1926).

${ }^{10}$ Ex parte Allen, 221 Ala. 393, 128 So. 801 (1930).
} 
difficult to avoid a suspicion that courts have been moved to modify decrees on the basis of their reaction to the propriety or impropriety of the original award, and not, as claimed, on the theory that subsequent conditions have rendered its enforcement unfair. It is not surprising, therefore, to find a court rebelling at the requirement of "changed circumstances."

In Cohen v. Cohen, ${ }^{17}$ the husband ${ }^{18}$ applied for a reduction in his alimony payments from $\$ 25$ to $\$ 15$ a week on the ground he was unable to pay over that sum. Although he neither alleged nor proved that the conditions of the parties had changed since the time of the decree, he was granted the reduction. The applicable statute authorized the revision of the decree "from time to time as circumstances may require," and it was held in an opinion by the lower court that an application for modification should be decided "in accordance with the very right of the matter at the time it is before the court for disposition, ... in accordance with equity and good conscience." The requirement that changed circumstances be shown, said the court, necessitated an examination of the factors on which the original order was based. This is rendered difficult by the fact that in most cases the testimony of the parties in the divorce action is not readily obtainable; often it has been made in the course of a final hearing and it has not been preserved. "More than once," said the judge, "I have been detained while I sought, without success, to ascertain the basis of an order for payment made some years before." The court, however, recognized the danger of a universal application of the policy it pretended to adopt by warning that only "meritorious applications" would be considered and that "petitions without merit will not only be discouraged but will trouble the applicant."

The notion that a decree which is inequitable at the time it is sought to be modified cannot be changed simply because it was also inequitable at the time it was granted may be offensive to one's sense of justice, and the practical difficulties encountered in obtaining the evidence adduced before the court in the divorce action should not be underestimated. But the rule adopted in Cohen v. Cohen is no less subject to practical objections. What criterion should the applicant employ to determine in advance whether his application is meritorious or otherwise, and what effective check would there be against attempts by parties to attack a decree collaterally, when they are precluded from doing so directly? Such a procedure would amount in many cases to a retrial of the same issues in clear violation of the established doctrine of res judicata.

Since the establishment of changed conditions is generally a condition precedent to relief, it becomes pertinent to inquire what new circumstances will warrant a modification of the alimony order. The decision of the lower court with respect to this issue will not be overruled on appeal unless its action constitutes a clear abuse of discretion. The difficulties encountered in estimating what amounts to such an abuse are the same as those presented by the appellate reports where the original

${ }^{17}{ }_{15}$ N. J. Misc. 666, 194 Atl. 257 (1937).

${ }^{28}$ In the interests of convenience, the terms "husband" and "wife" will be used, although technically inaccurate because of the dissolution of the marriage. 
award is under review. Since the problem of control of the lower court's discretion is treated at some length in the course of a study of original awards included in this symposium, ${ }^{10}$ no special consideration will be devoted to that aspect of the problem in this article.

The ability of the husband to make the payments and the needs of the wife may be said to constitute the basic alimony equation. In principle, therefore, a change in either of these two factors should bring about a change in the result, and this is apparently the theory upon which the decree is altered. In practice, however, the seeming simplicity of the equation is disturbed by the fact that the two basic considerations mentioned are not the only determinants of the award and that for obvious reasons it is inexpedient to amend the order when the change is insignificant. ${ }^{20}$

Attention will first be given to the circumstances which effect variations in the husband's ability to pay the sum decreed. That "one cannot get blood out of a turnip" is a truism particularly applicable to an improvident husband, and' a reduction in the source from which the payments are made should lead to a reduction in the payment. A decline in the husband's monthly salary from $\$ 400$ to $\$ 175$ has been held to warrant a decrease in the alimony payable by him from $\$ 15^{\circ}$ to $\$ 87.5^{\circ}$ per month, ${ }^{21}$ while demotion of an engineer to the position of fireman with the consequent reduction in earnings from $\$ 250$ to $\$ 15^{\circ}$ monthly has induced a reduction in his payments from $\$ 45$ to $\$ 35$ a month. ${ }^{22}$ On the other hand, a fall in the husband's yearly earnings from $\$ 58,000$ to $\$ 16,000$ was held in another case ${ }^{23}$ to support a mod'ification of the decree from $\$ 12,000$ to $\$ 7,500$ per annum. A substantial drop in the price of a commodity which constitutes the husband's sole source of income, ${ }^{24}$ or a showing that his interest as remainderman under a trust has materially depreciated in value, ${ }^{25}$ or that a substantial part of his estate has become worthless since the award of the decree, ${ }^{26}$ have all been held to justify a decrease in the payments.

The acuteness of the financial depression in the early years of this decade and its burden on the professions was judicially noticed by the court in Williams $v$. Williams, ${ }^{27}$ wherein the payments of a divorced lawyer who had undergone bankruptcy proceedings were reduced from $\$ 500$ to $\$ 325$ a month on his showing that his present income was $\$ 10,900$ a year. In contrast is the attitude shown by the court in David $v$.

\footnotetext{
${ }^{10}$ Cooey, The Exercise of Judicial Discretion in the Award of Alimony, supra, at pp. 221-224.

${ }^{20}$ In Herrick v. Herrick, 3 I9 Ill. 146 , 449 N. E. 820 (I926), it was stated that in making a change in the alimony award, the court should take into consideration the property and income of the parties, their ages, health, and social conditions, and whether there are any children dependent upon one or both of them for support: For all the factors which are considered by the courts in making the award, see Cooey, The Exercise of Judicial Discretion in the Award of Alimony Cases, supra, at pp. 217-221.

${ }^{21}$ Miller v. Miller, II4 W. Va. 600, 172 S. E. 893 (1934), reversing the decision of the lower court.

22 Boquette v. Boquette, 215 Iowa 990,247 N. W. 255 (1933), affirming decision of the lower court.

22 Luedke v. Luedke, 215 Wis. 303, 254 N. W. 525 (1934).

"Hendricks v. Hendricks, 91 Utah 553,63 P. (2d) 277 (1937).

${ }^{25}$ Kennard v. Kennard, 87 N. H. 320, 179 Atl. 4 I $_{4}$ (x935).

26 Watson v. Watson, $1 \times 3$ W. Va. 267 , I68 S. E. 373 (1933).

${ }^{27} 12$ N. J. Misc. 641, 174 Atl. 423 (1934), in opinion by the lower court.
} 
David, ${ }^{28}$ where no sympathy was accorded to the pleas of the divorced husband for reduction of the award on the ground that the prevailing depression had greatly lessened his ability to make the required payments. Holding that the petitioner, in times of good fortune, should "have provided for all possible exigencies, including the one from which he now seeks to escape," the court observed that "no patience or sympathy is had for those who seek to take advantage of present conditions in order to foil an obvious and indisputable duty."

Allegations of ill health and physical incapacity on the part of the husband are usually accompanied by a showing of decreased income which will justify a reduction. Thus, where the petitioner had sustained injuries in an automobile accident which were found to have reduced his earning capacity as a physician, his present income being insufficient for his own support, the court cut the award from $\$ 200$ to \$100 a month. ${ }^{29}$ The husband has likewise been entitled to a modification of the order when he showed his health had been impaired and that he did not have sufficient funds to obtain necessary hospital treatment. ${ }^{30}$ But proof of ill health subsequent to the decree will not support a revision at the instance of the husband where it appears his earnings have increased. ${ }^{31}$

Unfortunately, the reported decisions in many cases furnish inadequate, if any, information concerning the financial status of the parties and therefore fail to throw any light on the issue of what constitutes a "substantial decrease" in income which will entitle the party to a downward revision of the decree. Apparently a showing by the husband that financial reverses have lessened or terminated his ability to meet the terms of the payments seldom fails to bring relief from the courts. A reduction from $\$ 35$ to $\$ 30$ a month in the man's compensation and indebtedness in the sum of $\$ 213$ have been held not to be a sufficient change of condition to warrant modification, ${ }^{32}$ but usually a refusal to revise the order on the basis of decreased income is induced by a finding that the applicant's allegations concerning his financial diffculties are inaccurate or untrue. Courts have denied the husband's application for reduction when they have found that his financial position was even better than at the time of the original decree..$^{33}$ In another case the petitioner's claim that his property and income had fallen in value, rendering it difficult for him to meet the $\$ 30$ weekly payments, failed to impress the court, which found that his annual income was $\$ 5,000$ (it is not stated what it was formerly) and that his second wife was gainfully employed. ${ }^{34} \mathrm{~A}$ much stronger case was presented by a petitioning husband who sought a reduction in his $\$ 285$ monthly alimony payments, but the court refused to grant him any relief although his income had admittedly fallen from

${ }^{28}$ I 46 Mise. $444,26 \mathrm{I}$ N. Y. Supp. 456 (1933), in opinion by the lower court.

${ }^{29}$ Junger v. Junger, 215 Iowa 636,246 N. W. 659 (1933), affirming the lower court's decision.

${ }^{30}$ Carson v. Carson, 87 Utah $x, 47$ P. (2d) 894 (1935), reversing the lower court's decision.

${ }^{31}$ Kirk v. Kirk, 222 Iowa 945,270 N. W. 432 (1937).

32 Carson v. Carson, supra note 29.

${ }^{33}$ Sauve v. Sauve, 243 Mich. 33, 219 N. W. 662 (1928); Texter v. Texter, 251 Mich. 53, 231 N. W. 140 (1928); Molema v. Molema, ro3 Cal. App. 79, 283 Pac. 956 (1930).

${ }^{34}$ Schweim v. Schweim, 233 Mich. 67, 206 N. W. 353 (1926), affirming decision of the lower court. 
$\$ 16,000$ to $\$ 7,000$ a year. ${ }^{35}$ The fact that he had failed to reduce his living expenses and lived in apparent luxury was doubtless the determining factor in the decision.

A party may not escape the obligations of an alimony decree by spending more than his income, ${ }^{36}$ nor, apparently, may he do so by deliberately refusing to work or to take advantage of his earning capacity. ${ }^{37}$ It follows that earning capacity, even in the absence of actual employment, is an element to be considered in determining the measure of alimony the husband shall be required to pay. ${ }^{38}$ In one case the wife sought an increase in the payments on the ground of her ill health. The husband claimed he earned only $\$ 2800$ a year, but the court concluded from the findings that he was capable of earning at least $\$ 6,000$ a year, which added to $\$ 3000$ he received from his great-grandfather's estate, made an annual income of $\$ 9,000$, and the award was increased from $\$ 720$ to $\$ 4,000$ a year for the support of the wife and a 55 -year-old daughter. ${ }^{39}$

An increase in the income or property of the husband may be made the basis for an upward revision of the alimony decree in favor of the wife. Since the period considered in this report was in the main one of falling prices and reduced incomes, such petitions by the wife were infrequent. ${ }^{40}$ It is probable, moreover, that in the long run applications for modifications by the party on whom the burden rests to make the payments will outnumber petitions by the recipient for additional awards, inasmuch as the pressure on the former to seek judicial relief is undeniably greater. Still, the courts will not refuse to entertain applications for increased alimony where they are well founded. For instance, upon proof by the wife that her divorced husband had come into money as beneficiary of a trust estate subsequent to the decree, entitling him to about $\$ 5,000$ a year, the decree was revised to call for additional payments of $\$ 150$ a month. That the trustees had not actually paid the amount due and that the trust was a "spendthrift trust," exempting the beneficiary's income from the claims of creditors, did not deter the court from its decision. ${ }^{41}$ An increase in the husband's salary from $\$ 2,000$ to $\$ 10,000$ a year and a rise in the cost of living have been held to warrant an increase in the monthly payments to the wife from $\$ 60$ to $\$ 150$ "to correspond with the social position of her former husband and maintain her in the style and condition that his financial position would reasonably have justified her in maintaining but for his wrongful conduct [which led to the divorce]." 42 In Faye v. Faye ${ }^{43}$ the court upheld a $\$ 900$ increase in the annual payments for the support of the wife and child, notwithstanding the husband's financial means had not improved, on the ground that the original allowance had failed to provide for med-

\footnotetext{
${ }^{35}$ Heard v. Heard, i16 Conn. 632, I66 Atl. 67 (1933), affirming decision of the lower court.

${ }^{30}$ Moore v. Moore, I63 Miss. I5, 140 So. 526 (I932), affirming the lower court's decision.

${ }^{37}$ Robins v. Robins, ro6 N. J. Eq. 198, 150 Atl. 340 (1930).

${ }^{38}$ Faye v. Faye, I31 Misc. 388, 226 N. Y. Supp. 729 (1928).

${ }^{30}$ Farlee v. Farlee, ror N. J. Eq. Irr, 137 Atl. 648 (r927).

${ }^{\circ}$ Only four petitions by the wife for modification of the award on the ground of the husband's increased income are cited by the Fourth Decennial Digest, 1926-1936.

${ }^{41}$ Erickson v. Erickson, I8x Minn. 42r, 232 N. W. 793 (I930), affirming decision of the lower court.

${ }^{42}$ Humbird v. Humbird, 42 Idaho 29, 243 Pac. 827 (I926), modifying decision of the lower court.

${ }^{43}$ I3I Misc. 388,226 N. Y. Supp. 729 (r928).
} 
ical and dental expenses, the child's vacation needs, and repairs to furniture, and that the husband's earning capacity should be considered.

However, much fluctuations in the income of the husband may be grounds for the amendment of the decree, the courts are apparently committed to the rule that his remarriage and its attendant financial burden may not be successfully urged in support of a petition for modification. ${ }^{44}$ Voluntary assumption of new family obligations which diminish the husband's ability to comply with the terms of the decree should not, it is thought, avail him in avoiding the duty to support his former wife which is embodied in the alimony order. Furthermore, the father's subsequent marital engagements should not be allowed to jeopardize the maintenance of the children of his first marriage and insofar as there is a conflict between the husband's duties to his first family and to his new family the inclination seems to be to resolve it in favor of the former. The policy is doubtless intended to discourage future marital alliances on the part of those whose financial means are inadequate for the support of both families. In Neuhangen $v$. Neuhangen ${ }^{45}$ the court, while refusing to modify the decree at the instance of the husband who alleged his remarriage, attempted to impress him with the gravity of marital obligations and remarked: ". . he has yet to learn, it would seem, that getting married is serious, and marrying a second time while the bride he first led to the altar, and those born of that marriage, must be supported, is still more serious."

Where there are no children, however, a different attitude may prevail. This is illustrated by the decision in Lamborn $v$. Lamborn ${ }^{46}$ wherein the husband applied for a reduction in the payments on the ground he wished to remarry and that his divorced wife could earn money for her support. In upholding a decrease in the alimony from $\$ 45$ to $\$ 30$ a month, the court held it was proper to consider the laudable wish of the husband, who had no children, to remarry and that he should not be so crippled in his finances as to preclude the establishment of another home.

Although his remarriage is seldom alleged by the husband as the sole basis for invoking modification of the decree it is very often to be found among the grounds upon which the petition is founded, usually in conjunction with claims of reduced income. This indicates a notion that in spite of rules to the contrary such a circumstance will reflect favorably upon the petitioner's case. Such a notion may often be well founded, for it is arguable that the demands of a man's new family should be preferred to those of a family with whom he has severed all social connections. A failure to give adequate consideration to the husband's new obligations may lead to marital discord and to the break-up of a happily constituted marriage to enable the husband to bear the burden of a former marriage which has already been dissolved. But courts usually are adamant against granting relief where the factors alleged in

\footnotetext{
4 Stone v. Stone, 212 Iowa 1344, 235 N. W. 492 (1931); Williams v. Williams, 119 Ncb. 8, 226 N. W. 798 (1929); Aiken v. Aiken, 22I Ala. 67, 127 So. 819 (1930); Simpson v. Simpson, 51 Idaho 99, 4 P. (2d) 345 (1931).

${ }^{58} 92$ Colo. 155, 18 P. (2d) 454 (1934). $\quad 3080$ Cal. App. 494, 25r Pac. 943 (1927).
} 
support of the petition, exclusive of the remarriage, are insufficient to warrant modification. ${ }^{47}$

Where there are children of the second marriage the tendency would seem to be toward greater leniency, although even here some courts are unmoved. In one case it was held that remarriage of the husband and his obligation to support four stepchildren was not a "change of conditions," although it appeared that a son by the first marriage had already reached his majority and could support his mother. ${ }^{48}$ In another, a showing by the petitioning husband that he had remarried and had three new children, that he was afflicted with a heart disease, and that he was to be pensioned off shortly with a material reduction in income did not avail him in obtaining relief. ${ }^{49}$ A more realistic approach is taken by some courts, such as that in Shattuck $v$. Shattuck, ${ }^{50}$ where a reduction in the alimony payments from $\$ 50$ to $\$ 20$ a month was upheld under similar circumstances and it was said to be "the duty of the court to make a fair division of respondent's income between the two families. . . . He has as much duty to, and the court has as much interest in, those children [of the second marriage] as those of the first marriage." Another court held that the new family obligations of a husband who had remarried and had a child were to be considered, in addition to a decrease in his salary, in reducing his monthly alimony payments. ${ }^{51}$ Similarly, a court has refused to increase the award upon petition by the wife, although his income had risen, for his financial burdens had mounted on his remarriage and birth of another child, and "his obligations to these had to be met." Lord $v$. $\operatorname{Lord}^{53}$ intimates that a showing by the husband that the burden of the decree precludes him from furnishing adequate support to his new wife will warrant modification of the decree. In that case a petition alleging remarriage and support of a stepson was held insufficient to entitle the husband to a reduction since it was unaccompanied by a showing of inability to support his present wife suitably.

Attention is now turned from the first variable, the husband's ability to pay, to a consideration of the second major component of the basic alimony equation, the needs of the wife. A substantial change in the requirements of the divorced wife for her support should furnish the basis for a modification of the alimony order. The ability of the wife to earn her own living is a factor which enters into the computation of the original award. Acquisition of earning capacity and actual employment after the decree have been held not to support a decrease in the payments upon application by the husband. ${ }^{54}$ On the other hand, in Lamborn v. Lamborn ${ }^{55}$ it ap-

47 Williams v. Williams, Aiken v. Aiken, both supra note 43. But remarriage of the husband will not preclude him from obtaining a reduction if other facts render modification expedient. Nicolls v. Nicolls, 211 Iowa II93, 235 N. W. 288 (193I).

${ }^{48}$ Cook v. Cook, I68 Wash. 649 , I3 P. (2d) 38 (1932), affirming decision of the lower court.

Morrison v. Morrison, 208 Iowa 1384,227 N. W. 330 (rg29), affirming decision of the lower court.

${ }^{10}$ I 4 I Wash. 600, 25 I Pac. 85 I (x927).

"Eddy v. Eddy, 264 Mich. 328, 249 N. W. 868 (1933), affirming lower court's decision.

62 Frank v. Frank, 287 S. W. 829 (Mo. App. x926), reversing lower court's decision.

${ }^{23} 37$ N. M. 24, 16 P. (2d) 933 (1933), reversing lower court's decision.

t Newburn v. Newburn, 2ro Iowa 639, 231 N. W. 389 (I93I), reversing lower court's decision.

${ }^{6}$ Supra note 45. 
peared that the wife, though incapacitated by reason of illness to carry on her professional work as nurse, was able to engage in other types of work and earn a part of her living. Nevertheless, she showed a complete lack of disposition to contribute anything to her own support and the court dwelt at length upon this factor in reducing the monthly sum payable by the husband from $\$ 45$ to $\$ 35$. In view of the size of the original amount it is interesting to observe in the opinion the statement that a divorce court in awarding alimony where the husband earns his living by daily labor, "should not do so in a sum inducing idleness on the part of the wife." Similarly, it has been held that proof that the wife was now earning a monthly salary of \$I46 is sufficient to justify termination of the alimony payments of $\$ 250$ a month. ${ }^{50}$ The opinion fails to disclose what, if any, were the wife's earnings at the time of the decree. For a husband to obtain a modification of the decree without showing a change of condition on his part, he must establish that the wife is now selfsupporting. ${ }^{57}$

Physical injuries arising subsequent to the decree which make it impossible for the wife to contribute to her support were considered proper grounds for an alimony increase from $\$ 15$ to $\$ 75$ monthly in Curtiss v. Fisher. ${ }^{58}$ Ill health and medical treatment necessitating extraordinary expenses may also be asserted by the wife in obtaining a revision of the decree, ${ }^{59}$ or in successfully preventing a reduction in the payments at the husband's request. ${ }^{60}$ Where, in spite of ill health or financial reverses on the part of the wife there has been a corresponding decline in the husband's income it would seem that the "changes" would nullify each other and neither party should be able to obtain a revision. ${ }^{61}$ A wife may not, by voluntarily changing her residence to a location where her cost of living is higher, become entitled to additional alimony. ${ }^{62}$

The remarriage of the divorced wife is generally assumed to relieve the alimonypaying husband of the duty of supporting her, inasmuch as assumption of this obligation by the second husband will usually wipe out the need for further payments. The statutes of several jurisdictions make it mandatory upon the court to modify the decree upon the remarriage of the wife, provided, of course, application is made therefor. ${ }^{63}$ But in the absence of such statutory provision the courts are not unanimous in the view that this circumstance in itself is a proper basis for termination of the payments. Within recent years two New Jersey courts have differed in their

${ }^{56}$ Ross v. Ross, I Cal. (2d) 368, 35 P. (2d) 316 (1934), modifying decision of the lower court.

${ }^{67}$ Foltz v. Foltz, 28I Mich. 179, 274 N. W. 755 (1937).

${ }^{\text {ts }}$ x 86 La. 126, I71 So. 716 (1927), reversing lower court's decision.

${ }^{60}$ Rood v. Rood, 280 Mich. 33,273 N. W. 337 (1937), affirming lower court's decision. In Kelley v. Kelley, 290 S. W. 624 (Mo. App. I927), the wife's allegations that she could not work steadily at her cmployment because of physical inability were regarded with much scepticism by the court, who refused to increase the alimony and remarked that "the plaintiff has exhibited exceptional ability to take care of herself in adverse circumstances."

${ }^{\circ 0}$ Molema v. Molema, supra note 32.

${ }^{\text {a1 }}$ No case, however, was found involving this situation.

${ }^{62}$ Brassert v. Brassert, 269 Mich. 545, 257 N. W. 879 (1935), affirming lower court's decision.

${ }^{03}$ See 2 Vernier, Amertcan Family Laws, \$106. 
interpretation of the effect of the wife's remarriage. In Dietrick $v$. Dietrick ${ }^{64}$ the court relieved the husband from the duty of making further payments under the decree upon his showing of the remarriage of the wife. It was there held that this event raises a presumption that the necessity for alimony no longer exists, subject to rebuttal on the part of the wife by proof that the second husband is unable to support her in the manner and station of the first husband, which the wife failed to do in that case. On the other hand, in Cropsey v. Cropsey, ${ }^{65}$ the court refused to modify the decree upon the wife's remarriage and, in contrast to the "presumption" theory above, held the husband had failed to sustain the burden of proving that the wife was not in need of further payment. In another case proof that the wife had married a man of "considerable means" was considered sufficient to discontinue the alimony award. ${ }^{68}$ A man may not, however, without the court's sanction, cease the payments when his divorced wife contracts a new marriage, and he will be liable for the unpaid alimony which accrued until the time application is made for termination. ${ }^{67}$

An anomalous situation is presented where the divorced parties have intermarried again. A few jurisdictions provide in their statutes that upon application by both parties and satisfactory proof of their intermarriage, the court "may" annul the orders relating to the payment of alimony. ${ }^{68}$ The inference may be drawn therefrom that intermarriage does not ipso facto abrogate the duty of the husband to satisfy the terms of the decree. In Carson v. Carson, ${ }^{69}$ however, it was held that remarriage of the parties to each other annuls the decree and neither party may seek to enforce or modify its terms. Though clearly obiter, the court intimates that where the second marriage has been judicially dissolved the provisions of the original alimony decree might be enforced.

The husband cannot escape the duty of supporting his children because his wife has remarried. ${ }^{70}$ The divorce decree may make separate allowance for the support of the children, or the provisions for their maintenance may be embodied in the general alimony award granted to the wife. Whichever method is used, the payments for their benefit may be changed for reasons substantially identical to those which obtain in the case of payments for the benefit of the wife. They may be increased where they have become inadequate or the wife has become helpless and unable to contribute to their support, or they may be decreased where the husband's income has fallen, or illness has caused him large expense, or the wife has inherited property on her own account. ${ }^{71}$ The husband may likewise be freed from the duty of paying for

ot 99 N. J. F.q. 7 rr, 134 Atl. 338 (1926).

${ }^{60}$ 104 N. J. Eq. 187, 144 Atl. 621, 64 A. L. R. 1266 (1929).

${ }^{\circ 0}$ Shoop v. Shoop, 58 S. D. 593,237 N. W. 904 (r93I).

${ }^{\circ 7}$ Niedt v. Niedt, 95 S. W. (2d) 868 (Mo. 1936). Conceivably, much of the difficulty concerning revision upon the wife's remarriage may be circumvented by provision in the decree for continuation of the payments while the wife remains single. North v. North, roo S. W. (2d) 582 (Mo. I937).

${ }^{6}{ }_{2}$ Vernier, AMerican Family Laws, §io6.

io 143 Okl. 274, 288 Pac. 475 (1930).

${ }^{70}$ Cord v. Cord, 2x7 lowa 812, 253 N. W. $x 25$ (1934); Woodall v. Woodall, 204 Iowa 423, 214 N. W. 483 (1927).

${ }_{71}$ Kennard v. Kennard, I79 So. 660 (Fla. I938). 
their support when he shows they have become of age, or are self-supporting. ${ }^{\text {I2 }}$ It has been held, however, that unless an amount is separately awarded to the children, the decree awarding alimony should not be treated as conferring a separate award and subsequent removal of the children from the mother's custody may be ground for a diminution in the payments, but is not necessarily so. ${ }^{73}$ Marriage of a daughter, one of three children in the custody of the wife, has entitled the husband to a reduction in the award from $\$ 77$ a week to $\$ 250$ a month. ${ }^{74}$

The decision in the case of Fisher $v$. Fisher ${ }^{75}$ indicates a judicial reluctance to shift the burden of supporting the wife from the divorced husband to the children when the latter have grown up and are capable of earning income. Although it was shown that the children were substantially contributing to the support of their mother, the court refused to terminate the payments and held the circumstances alleged could not relieve the husband of his responsibilities.

Immoral conduct on the part of the wife subsequent to the decree is sometimes asserted by the husband as a basis for discontinuance of his alimony obligations. The moral quality of the post-divorce behavior as a factor of pertinence in modification cases stands in a category sui generis and bears no relation to the basic alimony equation to which allusion has been made. Divorce decrees, particularly in England, sometimes contain a provision for payment of alimony to the wife dum casta vixerit, which frees the husband from the duty of contributing to the wife's support when she has been guilty of unchastity and, in some instances, other moral derelictions. ${ }^{70}$ In the absence of such a provision, it is arguable that a wife who has been granted a divorce a mensa et thoro is under a duty to her husband to abstain from the type of conduct which would ordinarily enable him to secure a divorce of his own right. Failure to observe this duty should properly justify termination of the alimony payments, and it was so held in Gloth $v$. Gloth.$^{77}$ The argument is hardly applicable to cases of absolute divorce, where the marriage relation has been completely severed and the ordinary duties attendant upon that relation have ceased to exist, except insofar as the husband's obligation to furnish support is incorporated in the requirement to pay alimony. In such a case it is held that the wife, after the divorce, owes to the husband no greater duty to lead a pure and virtuous life than she owes to society generally, and proof that she has had illicit relations with men should not avail the husband in obtaining a modification of the decree. ${ }^{78}$ But in Lindbloom $v$. Lindbloom the court said that the wife's misconduct is a factor properly to be considered in reducing the alimony award. ${ }^{79} \mathrm{~A}$ recital in the decree that the wife recover per-

\footnotetext{
${ }^{72}$ Loomis v. Loomis, 273 Mich. 7, 262 N. W. 331 (1935); Smith v. Smith, 148 Atl. 900 (R. I. 1930); Brassert v. Brassert, supra note $6 \mathrm{r}$.

${ }^{73}$ Rochelle v. Rochelle, 235 Ala. 526, I79 So. 825 (1938).

${ }^{74}$ Conklin v. Conklin, 299 N. Y. Supp. 306 (1937).

${ }^{26} 237 \mathrm{Ky} .823,36 \mathrm{~S}$. W. (2d) 635 (1931), reversing lower court's decision.

${ }^{70}$ See 45 L. R. A. (N. s.) 880; (rgr3) Ann. Cas. rgr4D 597.

${ }^{77}$ Gloth v. Gloth, $x_{54}$ Va. 51 I, 153 S. E. 879, 7x A. L. R. 700 (1930), affirming lower court's decision.

${ }^{78}$ Cooley v. Cooley, 244 IIl. App. 488 (1928); Smith v. Johnson, 321 Ill. 134, 151 N. E. 550 (1926).

${ }^{79}$ I 80 Minn. 33, 230 N. W. II7 (I930), affirming lower court's decision.
} 
manent alimony "so long as she remains single and demeans herself in a proper manner" has been held to be observed although she had" consorted with men in noisy parties and partaken of intoxicating liquors. The decree, said the court, did not require her "to emulate St. Simeon Stylites if [she] wanted [her] alimony to continue." 80

The courts apparently look with disfavor upon agreements between the parties subsequent to the decree which purport to adjust the payments to changes in their circumstances. Behind this attitude is the fear that justice would often be thwarted by ignorance, undue influence, or deceit, and also stands the perennial judicial precaution against any individual action which will tend to oust the courts of their inherent jurisdiction to determine controversies and adjudicate the rights of the parties. In one case the court failed to uphold an agreement of the parties reducing the amount of the alimony allowance from $\$ 125$ to $\$ 45$ a month upon marriage of a daughter. ${ }^{81}$ It was suggested such a contract was against public policy and that it could neither supersede the original decree nor oust the court of its power to modify it. In another, the husband asked the court to vacate the order for payment, on the basis of a settlement entered into between the parties after the decree, and relief was denied on the ground that the wife had not been afforded the protection of the court in an inquiry as to the fairness, reasonableness, and adequacy of the settlement. ${ }^{82}$ In the absence of a holding that the contract is opposed to public policy it is likely that courts will promptly seize upon another factor which will justify cancellation of the contract. Evidence, admittedly meager, that the wife was ill and in an overwrought condition at the time the agreement was made modifying the terms of the alimony, has been held sufficient to nullify the contract, and the wife was permitted to recover the sum provided in the decree, less the amount received under the settlement. ${ }^{83}$

An analysis of the cases reveals a dearth of substantive rules that bind the courts in revising the alimony provisions of a divorce decree. It is evident that the question is not susceptible of determination by the application of rigid formulae. Even where the issues hinge on the increase or decrease of the income of the parties it is not possible to forecast the result by the use of simple rules of mathematics. In altering a decree the courts exercise independent judgment on the proper relation that the factors of income and property should bear to the size of the award, and the cases examined reveal that even where there has been a measurable change in the economic status of the parties, the amendment of the decree is not directly proportional to it. The courts have to deal with an almost innumerable variety of factors which may bear on the propriety of the change or the continued enforcement of the decree. Conditions on the one side must be weighed against conditions on the other and a neat balance struck which will represent an equitable compromise of conflicting interests. In view of the latitude of circumstances that must be considered, which make it

\footnotetext{
${ }^{80}$ Blakely v. Blakely, $216 \mathrm{Ky} \cdot 318,87 \mathrm{~S}$. W. (2d) 628 (I935).

${ }^{81}$ Capell v. Capell, I64 Va. 45, I78 S. E. 894 (1935).

${ }^{83}$ Dreir v. Dreir, rox N. J. Eq. 342, 139 Atl. 235 (1927).

${ }^{83}$ Hamlin v. Hamlin, 224 App. Div. 168, 230 N. Y. Supp. 5 I (1928).
} 
possible to differentiate every case on its facts, no more than a general categorization of the pertinent factors could be attempted. The necessity of flexibility in alimony decrees is imperative and the exercise of a wise discretion on the part of the trial judge, properly checked by recourse to appellate review, can probably do more to insure substantial justice in this field than any code of rules designed to direct the determination of these issues. However, it would not be prudent to overlook the consequences of a policy which would favor revision of an order upon each fluctuating change in the condition of the parties, regardless of decree. Aside from its encouragement of multiple and repeated invocations of judicial relief, it would introduce an element of uncertainty in the post-divorce relations of the parties which might seriously hamper the effective enforcement of the courts' decrees. A certain degree of permanence in the maintenance of the original award is therefore desirable. Where the alimony has become "a club of revenge and hate in the hands of the one, or a millstone about the neck of the other," 84 or where its enforcement would be attended by "positive wrong and injustice," imminent.

Much agitation for the alteration of a decree could be avoided by the framing of the original award with a view to reasonable and ordinary changes that may likely occur in the relations of the parties. Where factors which are reasonably certain to affect the circumstances of the parties can be anticipated, allowance therefor in the decree would preserve its essential soundness in the face of these changes. For instance, where there are no children and the parties are young, the possibility, probability and desirability of allowing the husband to remarry could well be considered, and future application by him for reduced payments might thereby be avoided. ${ }^{86}$ Or where the divorced wife is pregnant, allowance for the child to be born will prevent her from applying for additional payments for this support. ${ }^{87}$ The effect of the increasing age of the parties on the fundamental factors of ability and needs is usually considered in determining the original amount of alimony, and "age" is therefore not regarded as a change in circumstances. ${ }^{88}$

The exercise of a "wise discretion" on the part of the trial judge is rendered diffcult by the limitations on his ability to make a full and adequate investigation into all the circumstances affecting the parties. Reliance on their testimony, which is often conflicting, incomplete, and inaccurate, and the pressure of a crowded docket which places a premium upon time may often lead to ill-advised decisions. The creation of domestic relations courts and the extension of their powers to include matters of divorce and alimony would induce a degree of specialization that would promote efficiency and justice in the determination of such cases. Such a system, moreover, would contemplate the preservation and exposition of the evidence relied upon in

\footnotetext{
${ }^{84}$ Ruge v. Ruge, 97 Wash. 51, 165 Pac. 1063 (I917).

${ }^{80}$ Metzger v. Metzger, 278 N. W. 187 (Iowa, 1938).

${ }^{80}$ Lamborn v. Lamborn, supra note 45.

${ }^{87}$ Kiger v. Kiger, 205 Iowa 1200, 219 N. W. 314 (1928).

${ }^{88}$ MeNary v. McNary, 206 Iowa 942, 221 N. W. 580 (r928).
} 
making the alimony award and greatly facilitate the handling of future controversies between the parties. Appointment of an official amicus curiae $e^{89}$ offers the advantages of an impartial investigation into all relevant factors and a removal of most of the difficulties encountered in securing adequate evidence. Exclusive reliance by the court on the testimony of the investigator, however, is to be avoided as entailing the perils inherent in any inquisitorial system where the parties are not given a full opportunity to be heard. The most desirable method' would probably lie in permitting their testimony to be supplemented and confirmed by the investigator. The essential objective is the creation and maintenance of conditions which will permit the courts to operate with full knowledge of the facts. Once these are available, determination of the issues should be left largely to discretion, tempered by experience and a proper application of fundamental legal concepts.

${ }^{80}$ For a description of the work of the Friend of the Court in Detroit with regard to alimony proceedings, see Pokorny, Practical Problems in the Enforcement of Alimony Decrees, infra p. 274. 